\title{
GERMINATION AND OUTGROWTH OF A TEMPERATURE- SENSITIVE MUTANT OF BACILLUS SUBTILIS APPEARING TO HAVE A DEFECT IN RIBOSOMES
}

\author{
OSAMU KANAMITSU \\ Technical Research Laboratory, Asahi Chemical Industry \\ Co., Ltd., 27-36 Nakadai-3-chome, Itabashi-ku, Tokyo
}

(Received January 20, 1971)

\begin{abstract}
When the spores of a mutant of Bacillus subtilis appearing to have a temperature-sensitive defect in the ribosomes were incubated at $48^{\circ}$, the process of germination underwent naturally, but not the process of outgrowth. Moreover, dormant spores of this mutant were found to be less thermoresistant than those of the wild type strain.
\end{abstract}

Germination and outgrowth represent two processes which bacterial spores take before developing into vegetative cells. During the germination, the spores lose characters specific to dormant spores. Syntheses of RNA, protein, and DNA start in this sequence. Germination is followed by a process named outgrowth. Several investigators have shown that the germination process can be studied independently from the outgrowth process by employment of appropriate culture media (1), by addition of appropriate antibiotics (2), or by employment of appropriate auxotrophic mutants (3).

Previously, we reported on isolation and characterization of a mutant ( $t s-107)$ of Bacillus subtilis aprearing to have a temperature-sensitive defect in the ribosomes (4). The present work was undertaken to investigate how the defect in the ribosome might affect the process of germination and outgrowth. It was shown that the defect in $t s-107$ arrests development of the germinated spores into outgrowth step at $48^{\circ}$. Thermo-resistance of the dormant spore was also studied. The results of these observations are described.

\section{MATERIALS AND METHODS}

Strains. Bacillus subtilis Marburg strain $160(\operatorname{tr} p)$ and a temperaturesensitive mutant, $t s-107$, derived from 160 , were used. On the vegetative cells of this mutant, it has been reported to have temperature-sensitive ribosomes and to cease growth after a lapse of $1 \mathrm{hr}$ when the incubation temperature was shifted to $48^{\circ}$ from $37^{\circ}(4)$.

Sporulation agar medium. The medium contained, in $1,000 \mathrm{ml}$ (tap 
water), $\mathrm{KH}_{2} \mathrm{PO}_{4} 8.46 \mathrm{~g}$, $\mathrm{KOH} 2.26 \mathrm{~g}$, sodium citrate $2 \mathrm{H}_{2} \mathrm{O} 0.5 \mathrm{~g}$, $\left(\mathrm{NH}_{4}\right)_{2} \mathrm{SO}_{4}$ $1.0 \mathrm{~g}, \mathrm{MgSO}_{4} \cdot 7 \mathrm{H}_{2} \mathrm{O} 0.2 \mathrm{~g}, \mathrm{MnCl}_{2} \cdot 4 \mathrm{H}_{2} \mathrm{O} 0.01 \mathrm{~g}, \mathrm{CaCl}_{2} \cdot 2 \mathrm{H}_{2} \mathrm{O} 0.01 \mathrm{~g}, \mathrm{FeSO}_{4} \cdot 7 \mathrm{H}_{2} \mathrm{O}$ $0.01 \mathrm{~g}, \mathrm{CuSO}_{4} \cdot 5 \mathrm{H}_{2} \mathrm{O} 0.01 \mathrm{~g}$, meat extract $1.0 \mathrm{~g}$, yeast extract $1.0 \mathrm{~g}$, potato broth $(1 \mathrm{~kg}$ of diced potatoes immersed in $2,000 \mathrm{ml}$ of tap water was autoclaved at $120^{\circ}$ for $5 \mathrm{~min}$, and the extract was adjusted to $\mathrm{pH} 7.0$ with $\left.\mathrm{NaOH}\right) 150 \mathrm{ml}$, and agar $15 \mathrm{~g}$.

Germination-outgrowth medium. The medium contained, in $1,000 \mathrm{ml}$ of distilled water, sodium L-glutamate $3 \mathrm{~g}$, L-asparagine $0.3 \mathrm{~g}$, L-alanine $0.34 \mathrm{~g}$, L-arginine $\cdot \mathrm{HCl} 0.1 \mathrm{~g}$, Casamino acids (Difco) $0.5 \mathrm{~g}$, L-tryptophan $0.05 \mathrm{~g}$, glucose $10 \mathrm{~g}, \mathrm{D}$-fructose $1.0 \mathrm{~g}$, tris(hydroxymethyl)aminomethane (Tris) $12.1 \mathrm{~g}, \mathrm{NH}_{4} \mathrm{Cl}$ $0.5 \mathrm{~g}, \mathrm{KCl} 10 \mathrm{~g}, \mathrm{Na}_{2} \mathrm{SO}_{4} \cdot 10 \mathrm{H}_{2} \mathrm{O} 0.12 \mathrm{~g}, \mathrm{MgCl}_{2} \cdot 6 \mathrm{H}_{2} \mathrm{O} 0.5 \mathrm{~g}, \mathrm{MnCl}_{2} \cdot 4 \mathrm{H}_{2} \mathrm{O} 0.005 \mathrm{~g}$, calcium acetate $\cdot \mathrm{H}_{2} \mathrm{O} 0.02 \mathrm{~g}$, and $\mathrm{NaH}_{2} \mathrm{PO}_{4} \cdot 2 \mathrm{H}_{2} \mathrm{O} 0.156 \mathrm{~g}$. The $\mathrm{pH}$ was adjusted to 7.4 with $\mathrm{HCl}$.

Preparation of spores. Spore samples were prepared from the two strains stated above by the method of WAX et al. (1) with a slight modification. The cells were plated on the sporulation agar medium and incubated at $30^{\circ}$ for 10 days and the spores produced were collected in $0.01 \mathrm{M}$ Tris- $\mathrm{HCl}$ buffer ( $\mathrm{pH}$ 8.0). To remove contaminants, the spore suspension was treated first with $100 \mu \mathrm{g} / \mathrm{ml}$ of lysozyme (Tokyo Kasei Co.) for $60 \mathrm{~min}$ and then with $1 \%$ sodium dodecyl sulfate for $30 \mathrm{~min}$ at room temperature. The spores thus treated were washed 10 times with distilled water and suspensions in distilled water were stored at $4^{\circ}$. Microscopic examination indicated more than $95 \%$ of the observed particles were spores.

Induction of germination. Spores were inoculated in $5 \mathrm{ml}$ of germinationoutgrowth medium in an L-shaped tube so that the initial O.D.660 value would be 0.3 (approximately $6 \times 10^{7}$ spores $/ \mathrm{ml}$ ) as measured in a Hitachi spectrophotometer Model EPO-B. The tubes were shaken gently in a water bath at $37^{\circ}$ or at $48^{\circ}$. During the incubation, change in O.D.660 values was checked at intervals. The spores were not subjected to heat activation in these experiments in order to avoid the influence of heat treatment, because temperature sensitivity was the subject of this study.

Heat stability of dormant spores. Approximately $10^{5} / \mathrm{ml}$ spores in distilled water were heated at $80^{\circ}$ or at $90^{\circ}$ for indicated periods. The treated spores were plated on the agar plate containing Polypepton (Daigo Eiyo Co.) 0.5\%, meat extract $0.5 \%$, yeast extract $0.2 \%$, glucose $0.5 \%$, and agar $1.3 \%$ ( $\mathrm{pH} 7.0$ ), and incubated at $30^{\circ}$ for $48 \mathrm{hr}$. Percentages of surviving spores were calculated from the number of colonies appearing on the plates.

\section{RESULTS}

\section{Germination and outgrowth at $37^{\circ}$}

Figure 1 shows change in O.D.660 values and viable count of the spores of strains 160 and $t s-107$ during germination and outgrowth. In germinationoutgrowth medium at $37^{\circ}$, optical density at $660 \mathrm{~m} \mu$ decreased remarkably 


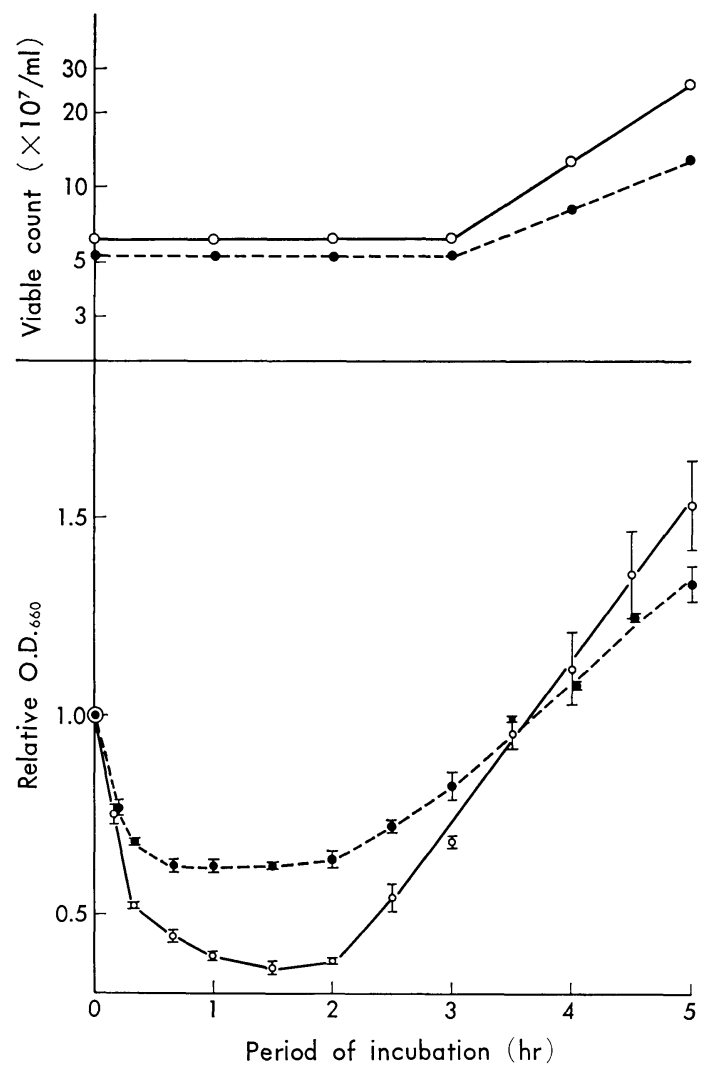

Fig. 1. Changes in optical density and viability of the spores during incubation at $37^{\circ}$.

Experiments were carried out in pairs.

Spores of 160 . Spores of $t s-107$.

within $1 \mathrm{hr}$ in both strains. Decrease in the spores of $t s-107$ was less than that in the spores of 160 . The spores harvested from $2 \mathrm{hr}$ incubation did not exhibit any dormant spore-specific characters such as light refractility, resistance to heat, and stainability with malachite green, suggesting that the incubated spores had completely developed into germinated spores. The optical density commenced to rise when $2 \mathrm{hr}$ elapsed. The rise in optical density during the incubation period of 2 to $3 \mathrm{hr}$ could be attributed to outgrowth of the spores, since no increment in viable count was observed during this period. The rise in optical density after $3 \mathrm{hr}$ might be due to both further growth of outgrowing cells and appearance of daughter cells.

Figure 2 shows morphological changes of the spores during the incubation. 


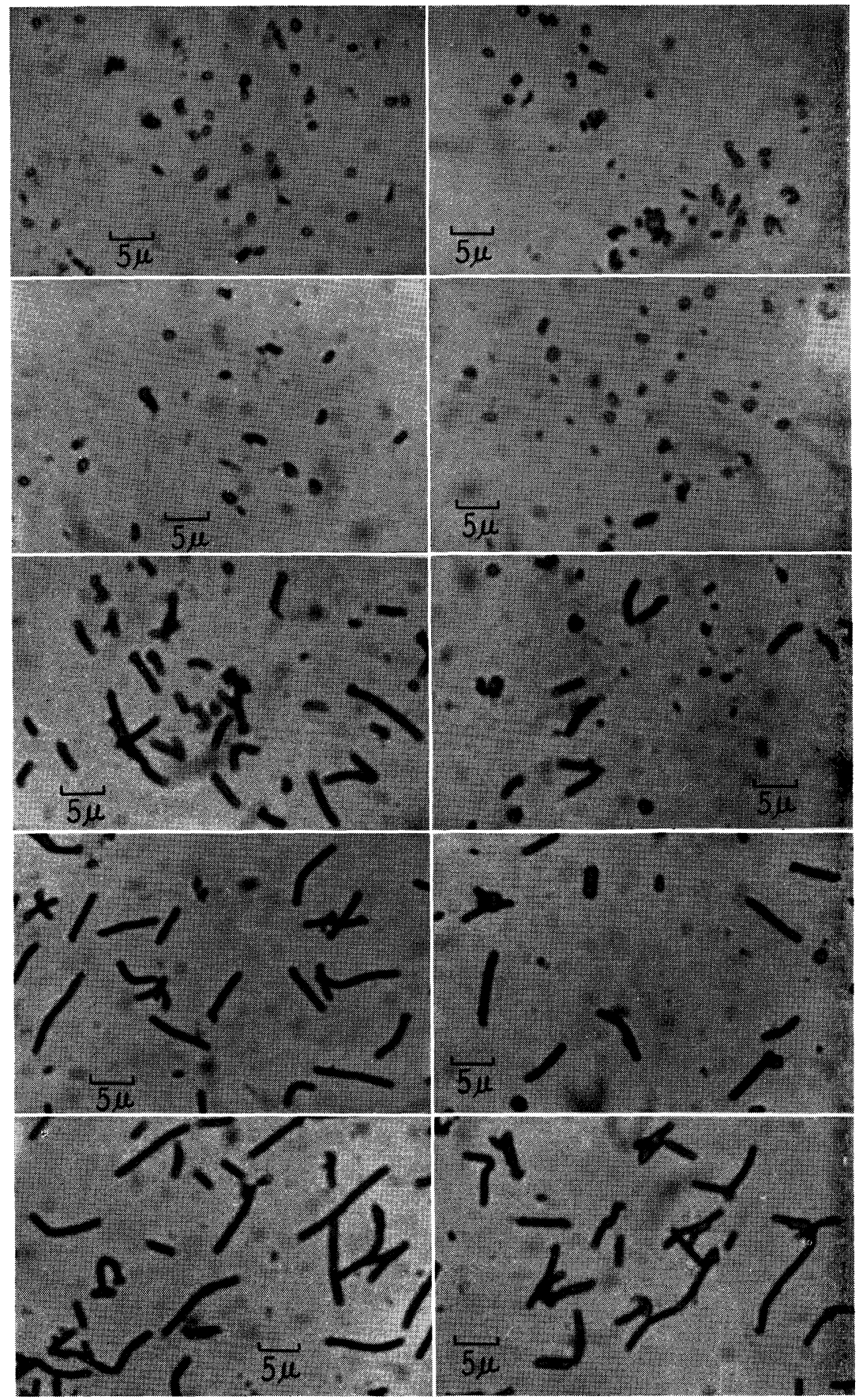

Fig. 2. 


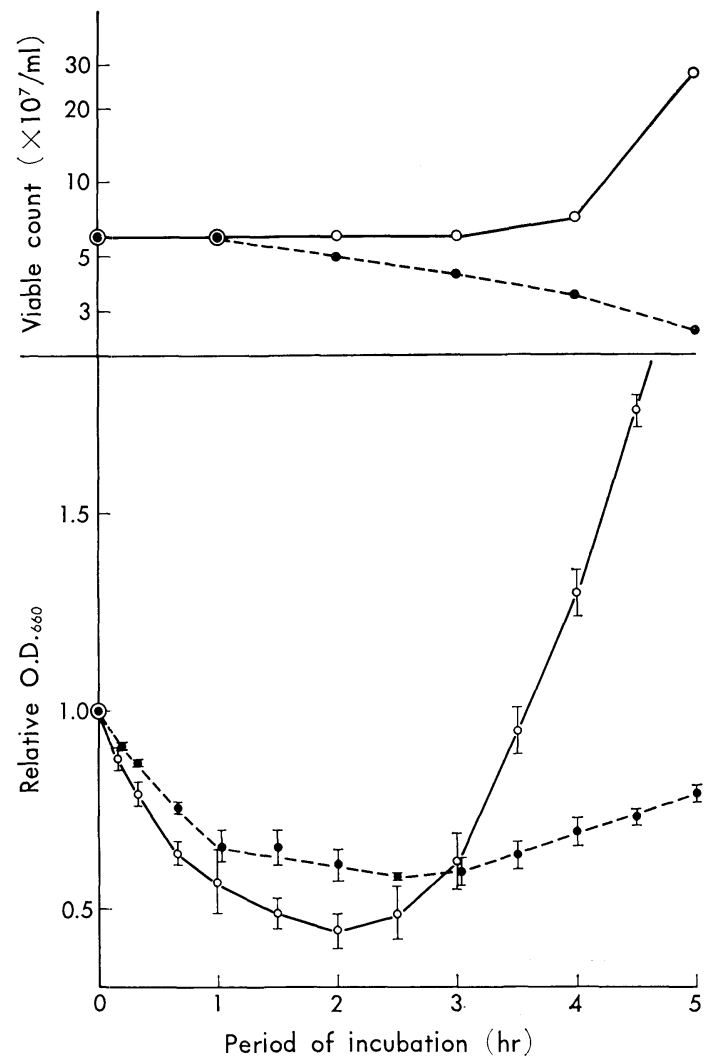

Fig. 3. Changes in optical density and viability of the spores during incubation at $48^{\circ}$.

\section{Experiments were carried out in pairs.}

○ Spores of 160 . Spores of $t s-107$.

\section{Germination and outgrowth at $48^{\circ}$}

Different results were obtained when these spores were incubated at $48^{\circ}$. The spores of strain 160 germinated and outgrew normally at this temperature, but the outgrowth process was not observed in the spores of $t s-107$. In the spores of $t s-107$, optical density decreased and dormant spore-specific characters were lost within $2 \mathrm{hr}$ as in those of 160 , but increase in optical

Fig. 2. Morphological changes in the spores during incubation at $37^{\circ}$.

Photomicrographs show morphology of the spores in samples harvested at 1,2 , 3,4 , and $5 \mathrm{hr}$ (from the top to the bottom) of incubation. Left: 160 . Right: $t s^{-}$ 107. 


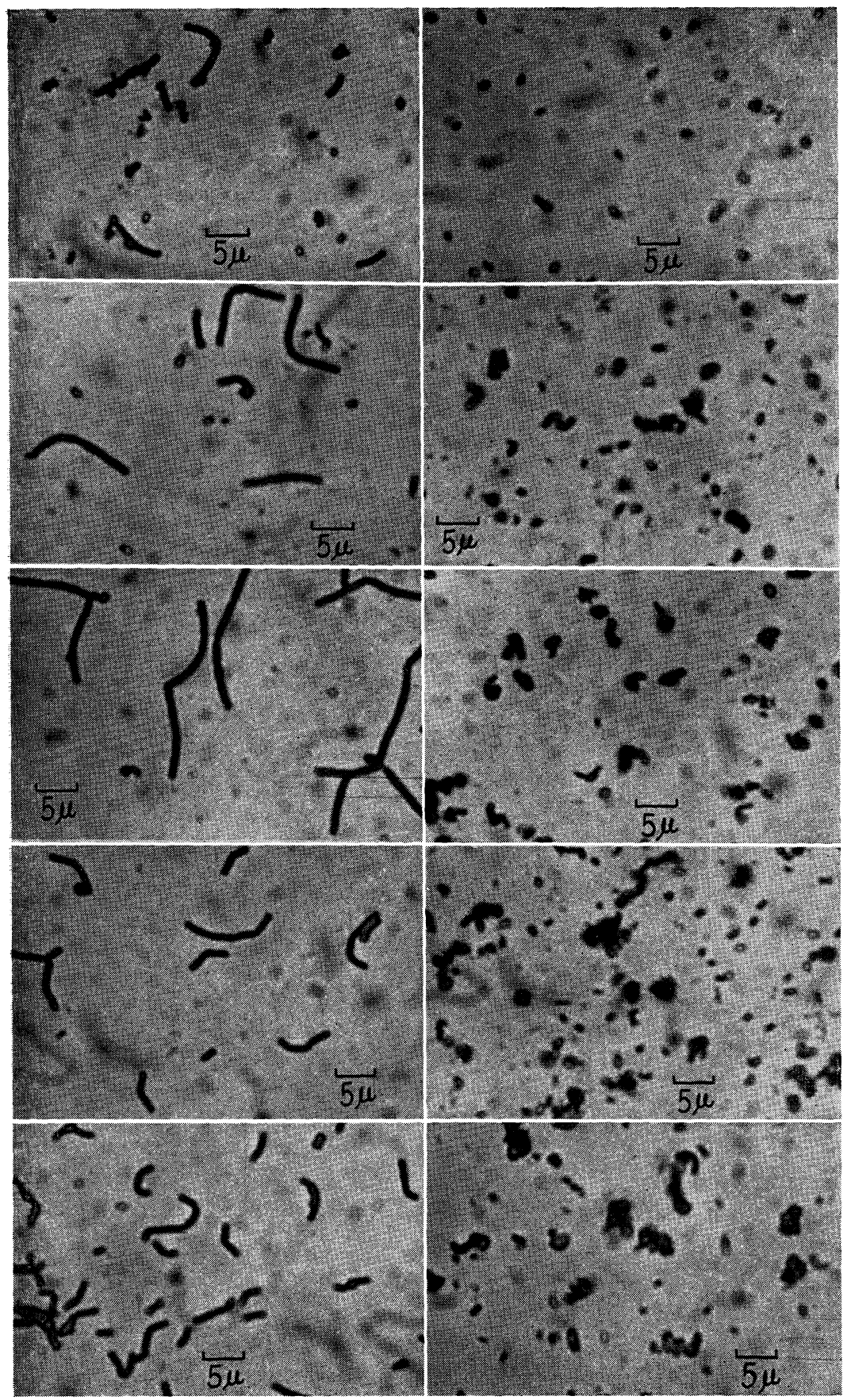

Fig. 4. 


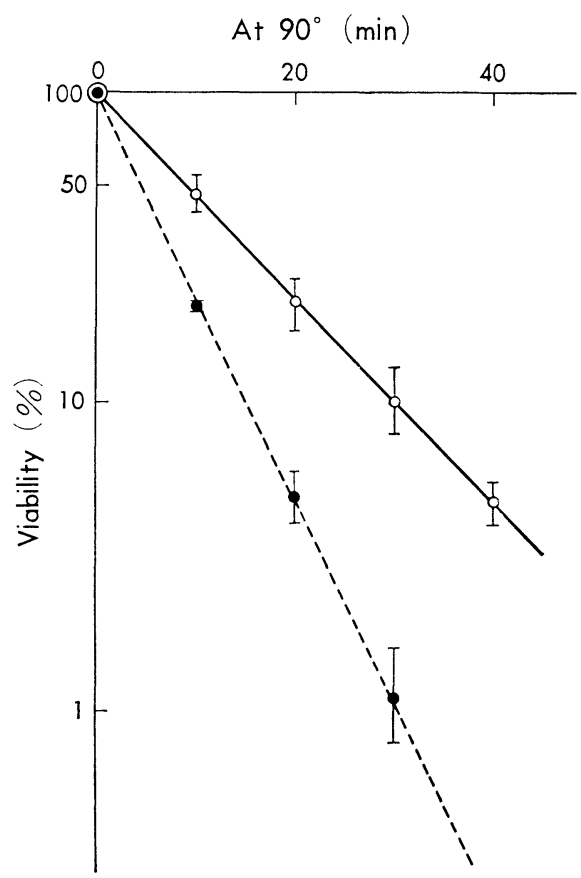

Fig. 5. Heat stability of the dormant spores.

Experiments were carried out in duplicate.

Spores of 160 . Spores of $t s-107$.

density after $2 \mathrm{hr}$ (as a result of outgrowth) was not observed (Fig. 3). Moreover, number of the viable cells decreased gradually.

Figure 4 shows morphological changes of the spores during the incubation. Spores of $t s-107$ failed to develop into vegetative cells, while those of parental strain (160) developed into vegetative cells via elongated cells. Most of the spores of $t s-107$ remained in the state of germinated spores, and less than $5 \%$ of the germinated spores developed into outgrowing cells. Interesting was the observation that cell morphology of these developed cells was not of the normal vegetative cell type. These cells were twisted severely, and took the form like a ball of knitting yarn. Photomicrographs in Fig. 4 were intentionally focussed on these irregular cells.

Fig. 4. Morphological changes in the spores during incubation at $48^{\circ}$.

Photomicrographs show morphology of the spores in samples harvested at 2,3, 4,5 , and $14 \mathrm{hr}$ (from the top to the bottom) of incubation. Left: 160 . Right: $t s^{-}$ 107. 


\section{Heat stability of the dormant spores}

Figure 5 shows heat stability of the dormant spores. Spores of both parental $(160)$ and mutant $(t s-107)$ strains did not lose viability at all when heated at $80^{\circ}$ for $60 \mathrm{~min}$. At $90^{\circ}$, both spores lost viability exponentially, and the loss of viability in $t s-107$ was more rapid than that in 160

\section{DISCUSSION}

It has been reported by DEMAIN and NEWKIRK (3) that the germination of $B$. subtilis spore can be commenced without synthesis of macromolecules, and other investigators (WOESE and FORRO (5), SAKAKIBARA et al. (2)) have suggested that the syntheses of RNA, protein and DNA occur in this sequence during the course of germination and outgrowth.

We reported previously (4) that mutant $t s-107$ appeared to have a temperature sensitive defect in the ribosome. Since ribosomes are indispensable for carrying out synthesis of protein, it is expected that spores of $t s-107$ are unable to develop into outgrowth phase at $48^{\circ}$. The results described in the preceding chapter meet the expectation. Spores of $t s-107$ failed to outgrow at $48^{\circ}$, although they could complete the process of germination. Thus, a mutant of the genus Bacillus having a mutational defect in the ribosome provides an excellent system for studying germination mechanism independently from outgrowth mechanism.

The observation that the $t s-107$ spores failed to outgrow at $48^{\circ}$ indicates that the ribosomes in the spores of $t s-107$ also have a temperature sensitive defect. If the low heat-resistance of the dormant spore observed in $t s-107$ is due to denaturation of this temperature sensitive factor, our observation implies a demonstration that a factor or a protein in a dormant spore can be either activated or inactivated by heat treatment.

The author expresses his hearty thanks to Prof. Y. IKEDA for helpful advice and for reading this manuscript.

\section{REFERENCES}

1) R. WAX, E. Freese and M. CASHel, J. Bacteriol., 94, 522 (1967).

2) Y. Sakakibara, H. Saito and Y. Ikeda, J. Gen. Appl. Microbiol., 11, 243 (1965).

3) A.L. Demain and J.F. Newkirk, J. Bacteriol., 79, 783 (1960).

4) O. Kanamitsu, Y. Kuroda, H. Saito and Y. Ikeda, J. Biochem. (Tokyo), 67, 353 (1970).

5) C.R. WoEse and J.R. Forro, J. Bacteriol., 80, 811 (1960). 